\title{
Synthesis, Anti-inflammatory and Antioxidant Activity of Mannich Bases of Dehydrozingerone Derivatives
}

\author{
Hayun Hayun*, Arif Arrahman, Euis Maras Purwati, Arry Yanuar, Fransisca Fortunata, Freddyhan Suhargo, Discka Winda Syafiqah, \\ Carissa Ignacia, Agnes Rebecca Novalia \\ Faculty of Pharmacy, Universitas Indonesia, Depok, 16424, INDONESIA.
}

\begin{abstract}
Objective: This study aims to synthesize a series of five new Mannich bases of dehydrozingerone (DHZ) derivatives and to evaluate for their antiinflammatory and antioxidant activity. Methods: The synthesis was performed by refluxing $\mathrm{DHZ}$ with formaldehyde and secondary amines, and the structures of the synthesized compounds were confirmed by FT-IR, ' $\mathrm{H}-\mathrm{NMR}$, ${ }^{13} \mathrm{C}-\mathrm{NMR}$, and HR-MS. The anti-inflammatory and antioxidant activity evaluations were done by inhibition of heat-induced albumin denaturation and a free-radical DPPH method, respectively. Results: All the synthesized compounds (2a-e) showed anti-inflammatory and antioxidant activity. The highest anti-inflammatory activity was shown by compound $\mathbf{2 c}$. The activity was comparable to the that of diclofenac sodium as a standard. While, the highest antioxidant activity was demostrated by compound $\mathbf{2 e}$. The compound showed moderate activity compared to that of quercetin as a standard. Mostly of Mannich base derivatives of $\mathrm{DHZ}$ compounds exhibited higher antioxidant activity than that of $\mathrm{DHZ}$. Conclusion: A series of five
\end{abstract}

new Mannich bases of DHZ (2a-e) was synthesized successfully. Compound $\mathbf{2 c}$ demonstrated anti-inflammatory activity which was comparable to diclofenac sodium, while compound $\mathbf{2 e}$ exhibited moderate antioxidant activity compared to quercetin as standard.

Key words: Dehydrozingerone, Mannich Bases, Synthesis, Anti-inflammatory, Antioxidant.

\section{Correspondence}

Hayun Hayun, Faculty of Pharmacy, Universitas Indonesia, Depok, 16424, West Java, INDONESIA.

Phone: +6221-8744738

Email: hayun.ms06@gmail.com, icapps2017.farmasiui@gmail.com

DOI: 10.5530/jyp.2018.2s.2

\section{INTRODUCTION}

Dehydrozingerone (DHZ), 4-(4-hydroxy-3-methoxyphenyl)-3-buten2-one (1), is a phenolic compound found as a minor component in the rhizomes of ginger (Zingiber officinale Roscoe). Structurally, DHZ is similar to a half of curcumin. Like as curcumin, the compound also exhibits a wide range of biological activities such as anti-inflammatory, antioxidant, antimicrobial, and cytotoxic activity. ${ }^{1-8}$ Various chemical modification of DHZ has been performed to exploit for diverse biological activities of DHZ derivatives, such as esterification or alkylation of $\mathrm{OH}$ phenolic group, replacement of $\mathrm{OH}$ with other substituents, substitution of the methoxy group, reduction of double bond, cyclization of $\alpha, \beta$ unsaturated carbonyl, and substitution of hydrogen atom bound to the carbonyl $a$-carbon. ${ }^{2,4,9-11}$ Some Mannich bases of DHZ have been synthesized and reported to have better anti-inflammatory activity compared to DHZ and fairly good anti-inflammatory activity compared to indomethacin. However, the aminomethyl group was substituted at the carbonyl $\alpha$-carbon of the compound. ${ }^{2}$ The substitution in the aromatic ring of DHZ with an aminomethyl group via Mannich reaction has not been reported yet. The Mannich reaction can take place between a phenolic compound containing one active hydrogen atom, secondary amines, and formaldehyde. The hydroxyl group in phenol is an electrondonating group making benzene very reactive to electrophilic substitution. ${ }^{12}$ In several cases, the Mannich derivatives of phenolic compound exhibit better biological activity than the corresponding parent analogs, such as several Mannich derivatives of diacetylresorcinol, resveratrol, hydroxycoumarin, hydroxybenzopyranone, and chalcone for antiinflammatory activity, and chalcone, thymol, and flavonone for antioxidant activity. ${ }^{12-15}$ Herein we report the synthesis, anti-inflammatory, and antioxidant activity of the Mannich bases of DHZ derivatives substituted on the phenyl ring.

\section{MATERIALS AND METHODS}

\section{Chemical Material and General Procedures}

All of the solvents, chemicals, and reagents were purchased from commercial sources (Sigma-Aldrich, USA; E. Merck, Germany; and Mallinckrodt, USA). Products purifications were performed using a flash column chromatographic method on silica gel 60, $0.063-0.200 \mathrm{~mm}$ (Merck, Germany). Purity test of the compounds was performed using TLC method on silica gel $60 \mathrm{~F}_{254}$ plates (Merck, Germany) and the spots were detected by UV-Vis lamp (Camag). Melting points were determined in one open-end capillaries method using Analogue Model SMP11 (Stuart Scientific, UK) and are uncorrected. Infrared (IR) spectra were recorded on an FT-IR Spectrophotometer (8400S, Shimadzu, Japan); NMR spectra were recorded on an NMR spectrometer (Agilent, USA) with console system DD2 at $500 \mathrm{MHz}$ for ${ }^{1} \mathrm{H}-\mathrm{NMR}$ and $125 \mathrm{MHz}$ for ${ }^{13} \mathrm{C}$-NMR, using TMS as internal standard and $\mathrm{CDCl}_{3}$ as solvents for all compounds; and the high-resolution mass spectra were recorded on a Water LCT Premier XE ESI-TOF mass spectrometer (Waters Corp., USA).

\section{Synthesis of dehydrozingerone (DHZ) (1)}

DHZ (1) was synthesized through condensation between vanillin and acetone $(1: 10, \mathrm{~mol} / \mathrm{mol})$ using a solution of potassium hydroxide as the catalyst as reported previously (Figure 1). Vanillin (20 gram; $0.1314 \mathrm{~mol}$ ) was dissolved in acetone $(80 \mathrm{~mL} ; 1089.4 \mathrm{mmol})$. Potassium hydroxide (11.2 g; $200 \mathrm{mmol})$ in $80 \mathrm{~mL}$ demineralized water was added

This is an open access article distributed under the terms of the Creative Commons Attribution-NonCommercial-ShareAlike 4.0 License, which allows others to remix, tweak, and build upon the work non-commercially, as long as the author is credited and the new creations are licensed under the identical terms. 
was neutralized with sulfuric acid (50\%) to obtain a yellow crystal. The product was filtered, washed with cool demineralized water, dried under vacuum in $75-80^{\circ} \mathrm{C}$, and purified by recrystallization from boiling demineralized water to afford pure $\mathrm{DHZ}(\mathbf{1})$.

\section{Synthesis of Mannich bases of dehydrozingerone derivatives (2a-e)}

The compounds (2a-e) were synthesized by amino-alkylation of DHZ (1) through a Mannich reaction (Figure 1) according to the method of synthesis of Mannich derivatives of vanillin and cyclovalone reported previously. ${ }^{16-17}$ Synthesis 2a-c: DHZ (1.92 g; $\left.10 \mathrm{mmol}\right)$ was added to a mixture of formaldehyde solution $(1.92 \mathrm{~mL} ; 15 \mathrm{mmol})$ and secondary amines $(15 \mathrm{mmol})$ in $9 \mathrm{~mL}$ of ethanol previously stirred for $30 \mathrm{~min}$, stirred for $30 \mathrm{~min}$, refluxed at $79^{\circ} \mathrm{C}$ for $30 \mathrm{~min}$, and then stirred until the reaction finished at $25^{\circ} \mathrm{C}$ for $2-7 \mathrm{~h}$. [Synthesis 2d-e: DHZ (1.92 g; $10 \mathrm{mmol})$ was added to a mixture of paraformaldehyde $(450.45 \mathrm{mg}$; $15 \mathrm{mmol})$ and secondary amines $(15 \mathrm{mmol})$ in $50 \mathrm{~mL}$ of acetonitrile previously heated at $80^{\circ} \mathrm{C}$ for $10 \mathrm{~min}$, stirred for $30 \mathrm{~min}$, and refluxed for $3-8 \mathrm{~h}$ ]. The progress of the reaction was monitored by TLC. After the reaction was completed, about $75 \%$ of the solvent was evaporated under reduced pressure and then refrigerated overnight. The product was filtered, washed with cold ethanol, dried under vacuum at $30-40^{\circ} \mathrm{C}$ and purified by flash column chromatography to afford pure compound 2a-e.

\section{In vitro anti-inflammatory assay}

The in vitro anti-inflammatory evaluation was performed using inhibition of heat-induced albumin denaturation method according to the previously reported with slight modification. ${ }^{18-19}$ The reaction mixture consisted of $1 \mathrm{~mL}$ of different concentration $(4,5,8,10,12 \mathrm{mM})$ of the test compounds or diclofenac sodium standard (purchased from PT Kimia Farma, Indonesia) and $1.4 \mathrm{~mL}$ phosphate buffer saline $\mathrm{pH} 6.3$ (purchased from Sigma-Aldrich, USA) were mixed with $25 \mu \mathrm{L}$ egg albumin obtained from fresh hen's egg (purchased from local supermarket), incubated at $37^{\circ} \mathrm{C}$ for $15 \mathrm{~min}$, heated at $70^{\circ} \mathrm{C}$ in water bath for $5 \mathrm{~min}$, and cooled to reach room temperature. The turbidity was measured as absorbance at $660 \mathrm{~nm}$ using UV-Vis spectrophotometer (V-530, Jasco, USA). For negative control was used the mixture of $1 \mathrm{~mL}$ of suitable solvent, 1.4 $\mathrm{mL}$ phosphate buffer saline $\mathrm{pH} 6.3$, and $25 \mu \mathrm{L}$ the egg albumin. The experiment was performed in triplicate, and the average of the absorbance

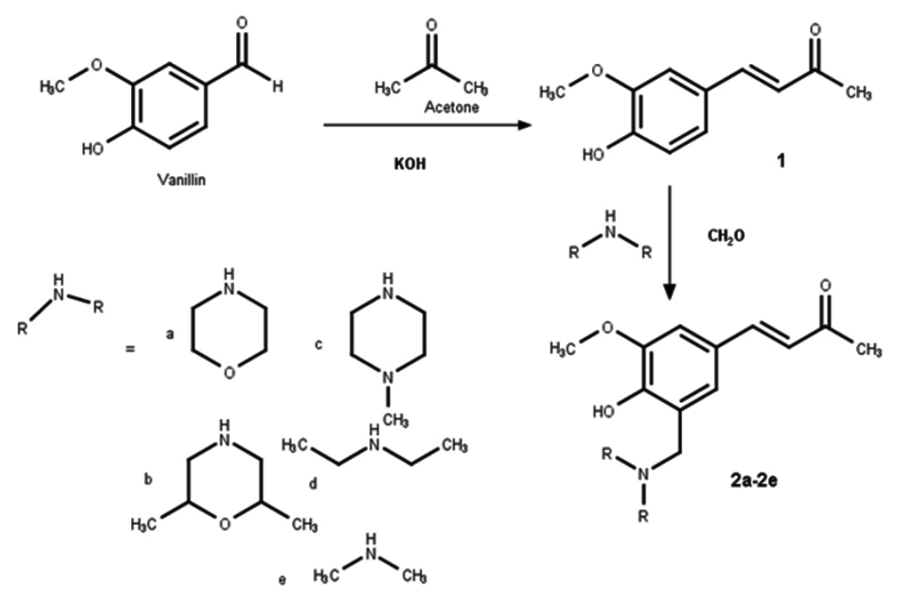

Figure 1: Scheme of the synthesis of Mannich bases of $\mathrm{DHZ}$ derivatives. was calculated. The percent of inhibition of albumin denaturation was calculated using the following formula:

$\%$ Inhibition $=\frac{\text { absorbance of control }- \text { absorbance of test solution }}{\text { absorbance of control }} \times 100 \%$

The concentration of the compound providing 50\% inhibition $\left(\mathrm{IC}_{50}\right)$ was obtained by plotting $\%$ inhibition versus concentration. A lower $\mathrm{IC}_{50}$ corresponds to the higher anti-inflammatory activity.

\section{In vitro antioxidant assay}

The antioxidant evaluation was performed using a free-radical 1,1'-diphenyl -2-picrylhydrazyl (DPPH) model system according to the methods previously reported ${ }^{20}$ with slight modification. The reaction mixtures consisted of $0.5 \mathrm{~mL}$ of different concentration of the test compounds (10-200 $\mu \mathrm{M})$ or quercetin standard $(6-35 \mu \mathrm{M})$ and $0.5 \mathrm{~mL}$ DPPH solution in methanol $(2.6 \mathrm{mM})$ were incubated at room temperature in the dark for $30 \mathrm{~min}$. The absorbance was measured at $517 \mathrm{~nm}$ using UV-Vis spectrophotometer (V-530, Jasco, USA). The control solution was prepared as the reaction mixture but without any test compounds and methanol was used for baseline correction. The experiment was performed in triplicate, and the average of absorbance was calculated. The percentage (\%) inhibition of radical scavenging activity was calculated using the following formula:

$\%$ inhibition $=\frac{\text { absorbance of control }- \text { absorbance of test solution }}{\text { absorbance of control }} \times 100$

The concentration of the compound providing $50 \%$ inhibition $\left(\mathrm{IC}_{50}\right)$ was obtained by plotting $\%$ inhibition versus concentration. A lower $\mathrm{IC}_{50}$ corresponds to the higher antioxidant activity.

\section{RESULTS}

\section{Chemistry}

The title compounds (2a-e) were synthesized stepwise by the methods summarized in Figure 1. The structure of synthesized compounds was confirmed by FT-IR, ${ }^{1} \mathrm{H}-\mathrm{NMR},{ }^{13} \mathrm{C}-\mathrm{NMR}$, and HR-MS.

\section{Physical and spectral data of synthesized compounds Dehydrozingerone (DHZ) (1)}

Yellow crystalline solid; yield 33\%; m.p. $126-128^{\circ} \mathrm{C}$ (according to literature $=129-131^{\circ} \mathrm{C}$ [3]). IR (KBr, cm-1) 3376-3225 (broad, OH), 3002 (C-H Ar), 2983, 2948, 2847 (C-H aliphatic), 1677 ( $\alpha, \beta$-unsaturated $\mathrm{C}=\mathrm{O}$ ), 1582, 1518 (C=C Ar), 1125, 1030 (C-O). ${ }^{1} \mathrm{H}-\mathrm{NMR}$ (500 MHz, CDCl3), S/ppm: 2.37 (s, 3H, CH3), 3.94 (s, 3H, OCH3), 5.92 (s, 1H, OH), 6.59 (d, 1H, J=16.2 Hz, CH=Cethenyl), 6.93 (d, 1H, J=8.2 Hz, HAr), 7.06 (d, $1 \mathrm{H}, \mathrm{J}=1.95 \mathrm{~Hz}, \mathrm{HAr}$ ), 7.09 (dd, $1 \mathrm{H}, \mathrm{J}=8.2 \mathrm{~Hz}$ and $1.9 \mathrm{~Hz}, \mathrm{HAr}), 7.45$ (d, $1 \mathrm{H}, \mathrm{J}=16.2 \mathrm{~Hz}, \mathrm{CH}=$ Cethenyl).

\section{4-[4-Hydroxy-3-methoxy-5-(morpholin-4-ylmethyl) phenyl]but-3-en-2-one (2a)}

Light yellow crystal; yield $20 \%$; m. p. $122-123^{\circ} \mathrm{C}$. HRMS ES- $(\mathrm{m} / z)$ : found 290.1392, calculated masses of $\mathrm{C}_{16} \mathrm{H}_{20} \mathrm{NO}_{4}: 291.1392$ (error 3.8 ppm). IR (KBr, cm ${ }^{-1}$ ): 3090 (C-H Ar), 2959, 2850 (C-H aliphatic), 1672 ( $\alpha, \beta$-unsaturated $\mathrm{C}=\mathrm{O}), 1649(\mathrm{C}=\mathrm{C}), 1591,1420(\mathrm{C}=\mathrm{C}$ Ar), 1161, 1117, 1078 (C-O). ${ }^{1} \mathrm{H}-\mathrm{NMR}\left(500 \mathrm{MHz}, \mathrm{CDCl}_{3}, \delta / \mathrm{ppm}: 2.34\right.$ (s, 3H, $\left.\mathrm{CH}_{3}\right), 2.59$ $\left(\mathrm{m}, 4 \mathrm{H},-\mathrm{CH}_{2}\right), 3.74\left(\mathrm{~m}, 2 \mathrm{H},-\mathrm{CH}_{2}\right), 3.76,3.75\left(\mathrm{~s}, 4 \mathrm{H},-\mathrm{CH}_{2}\right), 3.90(\mathrm{~s}, 3 \mathrm{H}$, $\left.\mathrm{OCH}_{3}\right), 6.55$ and $7.40\left(\mathrm{~d}, 1 \mathrm{H}, J=16.5 \mathrm{~Hz}\right.$, respectively, $\left.-\mathrm{CH}=\mathrm{CH}{ }_{\text {ethenyl }}\right)$, $6.83\left(\mathrm{~d}, 1 \mathrm{H}, J=0.7 \mathrm{~Hz}, \mathrm{H}_{\mathrm{Ar}}\right), 7.00\left(\mathrm{~d}, 1 \mathrm{H}, J=0.3 \mathrm{~Hz}, \mathrm{H}_{\mathrm{Ar}}{ }^{13} \mathrm{C}-\mathrm{NMR}(125\right.$ $\mathrm{MHz}, \mathrm{CDCl}_{3}$ ), $\delta / \mathrm{ppm}: 27.4$ (1C), 52.8 (2C), 55.9 (1C), 61.4 (1C), 66.7 
(2C), 110.0 (1C), 120.9 (1C), 122.4 (1C), 124.6 (1C), 125.6 (1C), 143.6 (1C), 148.4 (1C), 149.8 (1C), 198.12 (1C).

4-\{3-[(2,6-Dimethylmorpholin-4-yl)methyl]-4-hydroxy-5methoxyphenyl\}but-3-en-2-one (2b)

Pale yellow crystalline solid; yield 27\%; m.p. $153-155^{\circ} \mathrm{C}$. HRMS ES- $(\mathrm{m} / \mathrm{z})$ found 318.1705, calculated masses of $\mathrm{C}_{18} \mathrm{H}_{24} \mathrm{NO}_{4}: 319.1705$ (error 2.8 ppm). IR ( $\left.\mathrm{KBr}, \mathrm{cm}^{-1}\right): 3088$ (C-H Ar), 2972, 2845, 2821 (C-H aliphatic), 1660 ( $\alpha, \beta$-unsaturated $\mathrm{C}=\mathrm{O}), 1636(\mathrm{C}=\mathrm{C}$ aliphatic), $1621(\mathrm{C}=\mathrm{C}$ Ar), 1257, 1082 (C-O). ${ }^{1} \mathrm{H}-\mathrm{NMR}\left(500 \mathrm{MHz}, \mathrm{CDCl}_{3}\right.$ ), $\delta / \mathrm{ppm}$ : 1.15 and 1.16 (two s of $6 \mathrm{H}, \mathrm{CH}_{3}$ ), 1.89 and $2.82\left(\mathrm{t}, 2 \mathrm{H}\right.$ and $\mathrm{d} 2 \mathrm{H}$ of $-\mathrm{CH}_{2}-\mathrm{N}-\mathrm{C}$ ), 2.34 (s, $\left.3 \mathrm{H}, \mathrm{CH}_{3}\right), 3.71$ (s, $2 \mathrm{H},-\mathrm{N}-\mathrm{CH}_{2}$-Ar overlap with $2 \mathrm{H}, \mathrm{m},-\mathrm{CH}-\mathrm{O}-\mathrm{C}$ ), 3.90 and 3.91 ( two $\mathrm{s}$ of $3 \mathrm{H}, \mathrm{OCH}_{3}$ ), 6.56 and $7.41(\mathrm{~d}, 1 \mathrm{H}, J=16.1 \mathrm{~Hz}$, respectively, $\left.-\mathrm{CH}=\mathrm{CH}_{-}{ }_{\text {ethenyl }}\right), 6.83\left(\mathrm{~d}, 1 \mathrm{H}, J=1.9 \mathrm{~Hz}, \mathrm{H}_{\mathrm{Ar}}\right), 7.01(\mathrm{~d}, 1 \mathrm{H}$, $\left.J=2.0 \mathrm{~Hz}, \mathrm{H}_{\mathrm{Ar}}\right) .{ }^{13} \mathrm{C}-\mathrm{NMR}\left(125 \mathrm{MHz}, \mathrm{CDCl}_{3}\right), \delta / \mathrm{ppm}$ : 19.06 (2C), 27.49 (1C), 56.06 (1C), 58.47 (2C), 61.44 (1C), 71.78 (2C), 109.99 (1C), 121.10 (1C), 122.51 (1C), 124.75 (1C), 125.67 (1C), 143.77 (1C), 148.48 (1C), 150.07 (1C), 198.32 (1C).

\section{4-\{4-Hydroxy-3-methoxy-5-[(4-methylpiperazin-1yl) methyl]phenyl\}but-3-en-2-one (2c)}

Yellow powder; yield $70 \%$; m.p. $165-167^{\circ} \mathrm{C}$. HRMS ES- $(\mathrm{m} / \mathrm{z})$ found 303.1709, calculated masses of $\mathrm{C}_{17} \mathrm{H}_{23} \mathrm{~N}_{2} \mathrm{O}_{3}: 304.1709$ (error $3.3 \mathrm{ppm}$ ). IR (KBr, cm $\left.{ }^{-1}\right): 3082$ (C-H Ar), 2949, 2823, 2806 (C-H aliphatic), 1656 ( $\alpha, \beta$-unsaturated $\mathrm{C}=\mathrm{O}$ ), $1595(\mathrm{C}=\mathrm{C}), 1255,1087$ (C-O). ${ }^{1} \mathrm{H}-\mathrm{NMR}$ (500 $\mathrm{MHz}, \mathrm{CDCl}_{3}$ ), $\delta / \mathrm{ppm}: 2.29$ (s, 3H, $\left.\mathrm{CH}_{3}\right), 2.34\left(\mathrm{~s}, 3 \mathrm{H}, \mathrm{CH}_{3}\right), 2.55(\mathrm{~m}, 8 \mathrm{H}$, $\left.\mathrm{CH}_{2}\right), 2.74\left(\mathrm{~s}, 2 \mathrm{H}, \mathrm{CH}_{2}\right), 3.90\left(\mathrm{~s}, 3 \mathrm{H}, \mathrm{CH}_{3}\right), 6.55$ and $7.40(\mathrm{~d}, 1 \mathrm{H}, J=16.1$ $\mathrm{Hz}$, respectively, $\left.-\mathrm{CH}=\mathrm{CH}-_{\text {ethenyl }}\right), 6.82\left(\mathrm{t}, 1 \mathrm{H}, J=2.3 \mathrm{~Hz}, \mathrm{H}_{\mathrm{Ar}}\right), 6.99(\mathrm{~d}, 1 \mathrm{H}$, $\left.J=1.9 \mathrm{~Hz}, \mathrm{H}_{\mathrm{Ar}}\right) .{ }^{13} \mathrm{C}-\mathrm{NMR}\left(125 \mathrm{MHz} \mathrm{CDCl}_{3}\right), \delta / \mathrm{ppm}: 27.47$ (1C), 46.00 (1C), 52.57 (2C), 54.94 (2C), 56.05 (1C), 61.06 (1C), 109.94 (1C), 121.40 (1C), 122.50 (1C), 124.62 (1C), 143.89 (1C), 148.48 (1C), 150.34 (1C), $198.35(\mathrm{C})$

\section{4-\{3-[(Diethylamino)methyl]-4-hydroxy-5-}

methoxyphenyl\}but-3-en-2-one (2d)

Brown viscous oil; yield 32\%. HRMS ES- $(\mathrm{m} / z)$ found 276.1600 , calculated masses of $\mathrm{C}_{16} \mathrm{H}_{22} \mathrm{NO}_{3}: 277.1600$ (error $3.3 \mathrm{ppm}$ ). IR (KBr, cm ${ }^{-1}$ ): 3092 (C-H Ar), 2960, 2850 (C-H aliphatic), 1670 ( $\alpha, \beta$-unsaturated $\mathrm{C}=\mathrm{O}$ ), 1580 (C=C), 1260, 1160 (C-O), ${ }^{1} \mathrm{H}-\mathrm{NMR}\left(500 \mathrm{MHz}, \mathrm{CDCl}_{3}\right), \delta / \mathrm{ppm}$ : $1.13\left(\mathrm{t}, 6 \mathrm{H}, \mathrm{CH}_{3}\right), 2.34\left(\mathrm{~s}, 3 \mathrm{H}, \mathrm{CH}_{3}\right), 2.64\left(\mathrm{q}, 4 \mathrm{H}, J=7.15, \mathrm{CH}_{2}\right), 3.8$ (s, $\left.2 \mathrm{H}, \mathrm{CH}_{2}\right), 3.9\left(\mathrm{~s}, 3 \mathrm{H}, \mathrm{CH}_{3}\right), 6.56$ and $7.42(\mathrm{~d}, 1 \mathrm{H}, J=16.1 \mathrm{~Hz}$, respectively, $\left.-\mathrm{CH}=\mathrm{CH}{ }_{\text {ethenyl }}\right), 6.81\left(\mathrm{dd}, 1 \mathrm{H}, J=1.9 \mathrm{~Hz}, \mathrm{H}_{\mathrm{Ar}}\right), 6.98\left(\mathrm{~d}, 1 \mathrm{H}, J=1.9 \mathrm{~Hz}, \mathrm{H}_{\mathrm{Ar}}\right)$. ${ }^{13} \mathrm{C}-\mathrm{NMR}\left(125 \mathrm{MHz}, \mathrm{CDCl}_{3}\right.$ ), $\delta / \mathrm{ppm}: 11.30$ (2C), 27.44 (1C), 46.52 (2C), 56.04 (1C), 56.82 (1C), 109.74 (1C), 122.18 (1C), 122.32 (1C), 124.33 (1C), 125.01 (1C), 144.19 (1C), 148.53 (1C), 151.34 (1C), 198.44 (1C).

\section{4-\{3-[(Dimethylamino)methyl]-4-hydroxy-5- methoxyphenyl\}but-3-en-2-one (2e)}

Brownish orange powder; yield $39 \%$; m.p. $95-97^{\circ} \mathrm{C}$. HRMS ES- $(\mathrm{m} / \mathrm{z})$ found 248.1287, calculated masses of $\mathrm{C}_{14} \mathrm{H}_{18} \mathrm{NO}_{3}: 249.1287$ (error $3.6 \mathrm{ppm}$ ). IR (KBr, cm$\left.{ }^{-1}\right): 3009$ (C-H Ar), 2989, 2958, 2830, 2785 (C-H aliphatic), 1667 ( $\alpha, \beta$-unsaturated $\mathrm{C}=\mathrm{O}), 1616,1591(\mathrm{C}=\mathrm{C}), 1261,1080$ (C-O). ${ }^{1} \mathrm{H}-\mathrm{NMR}\left(500 \mathrm{MHz}, \mathrm{CDCl}_{3}\right.$ ), $\delta /$ ppm: 2.35 (d, 8H, J=6.0 Hz, $\mathrm{CH}_{3}$ ), 3.68 $\left(\mathrm{s}, 2 \mathrm{H}, \mathrm{CH}_{2}\right), 3,90\left(\mathrm{~s}, 3 \mathrm{H}, \mathrm{OCH}_{3}\right), 6.56$ and $7.41(\mathrm{~d}, 1 \mathrm{H}, J=16.0 \mathrm{~Hz}$, respectively, $\left.-\mathrm{CH}=\mathrm{CH}-_{\text {ethenyl }}\right), 6.82\left(\mathrm{~d}, 1 \mathrm{H}, J=2.0, \mathrm{H}_{\mathrm{Ar}}\right), 6.99(\mathrm{~d}, 1 \mathrm{H}, J=2.0 \mathrm{~Hz}$, $\left.\mathrm{H}_{\mathrm{Ar}}\right) .{ }^{13} \mathrm{C}-\mathrm{NMR}\left(125 \mathrm{MHz}, \mathrm{CDCl}_{3}\right), \delta / \mathrm{ppm}: 27.43$ (1C), $44.51(2 \mathrm{C}), 56.07$ (1C), 62.46 (1C), 110.02 (1C), 122.06 (1C), 122.35 (1C), 124.51 (1C), 144.05 (1C), 149.46 (1C), 150.77 (1C), 198.42 (1C).

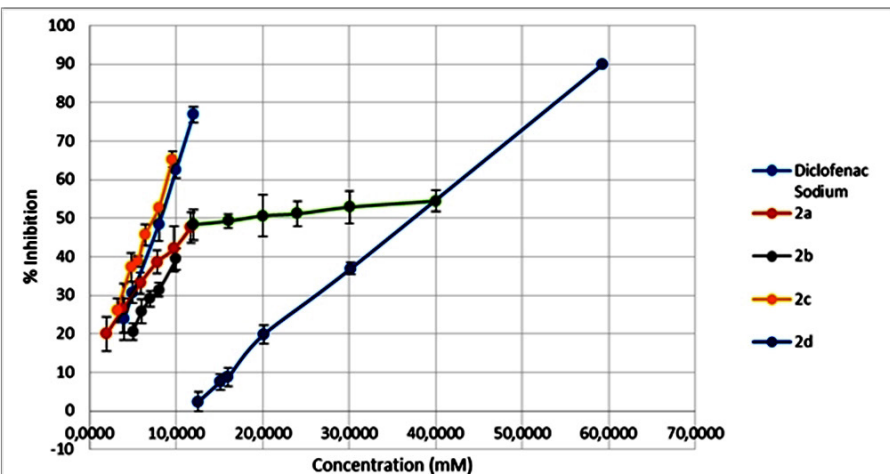

Figure 2: The inhibition of heat-induced albumin denaturation activity of synthesized compounds.

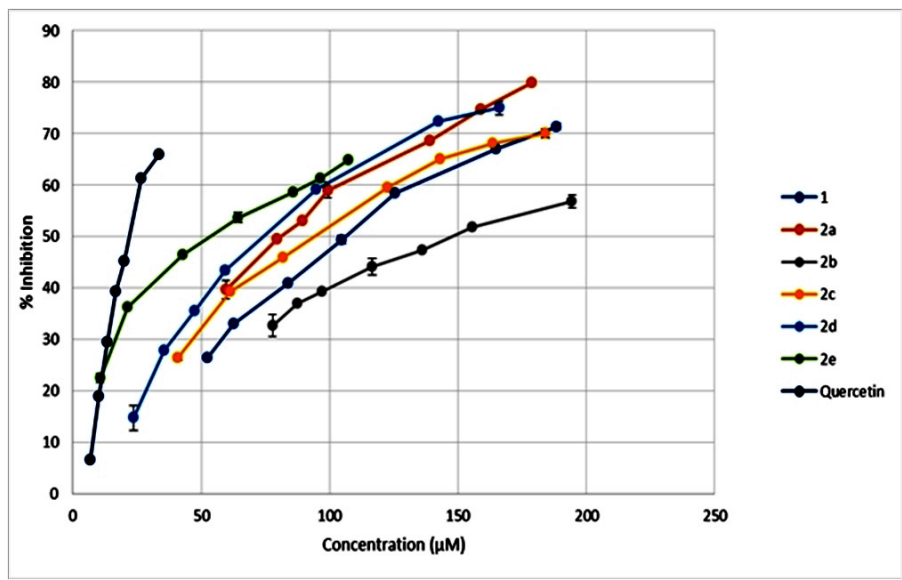

Figure 3: The DPPH radical scavenging activity of synthesized compounds.

\section{Anti-inflammatory and antioxidant activity}

The title compounds (2a-e) were screened for their anti-inflammatory and antioxidant activity. The anti-inflammatory evaluation was performed using an inhibition of heat-induced albumin denaturation method, while the antioxidant activity was done using a free-radical DPPH scavenging activity model system. Using the methods, we found that, the inhibition of heat-induced albumin denaturation activity and DPPH radical scavenging activity of the synthesized compounds were concentrationdependent (Figures 2 and 3). The $\mathrm{IC}_{50}$ values of the biological activity of the title compounds calculated from the dose-response data were displayed in Table 1.

\section{DISCUSSION}

Various chemical modification of dehydrozingerone (DHZ) has been performed to exploit for diverse biological activities of its derivatives., ${ }^{2,49-11}$ However, the substitution in the aromatic ring of the compound with an aminomethyl group via Mannich reaction has not been reported yet. In this study, a series of five novel Mannich bases of DHZ (2a-e) was synthesized. The IR spectra of the synthesized compounds showed the disappearance a broad peak of $\mathrm{OH}$ phenolic at $3200-3550 \mathrm{~cm}^{-1}$, and the appeared additional of peaks at between $2700-2970 \mathrm{~cm}^{-1}$ compared to that of compound 1 . These indicate the disappearance of intermolecular hydrogen bonding of the $\mathrm{OH}$ group and the addition of $\mathrm{CH}$ aliphatic chain of the compound 2a-e. The bands at $1078-1261 \mathrm{~cm}^{-1}$ correspond to 
Table 1: Anti-inflammatory activity (in vitro) and Antioxidant activity of the synthesized compounds (2a-e).
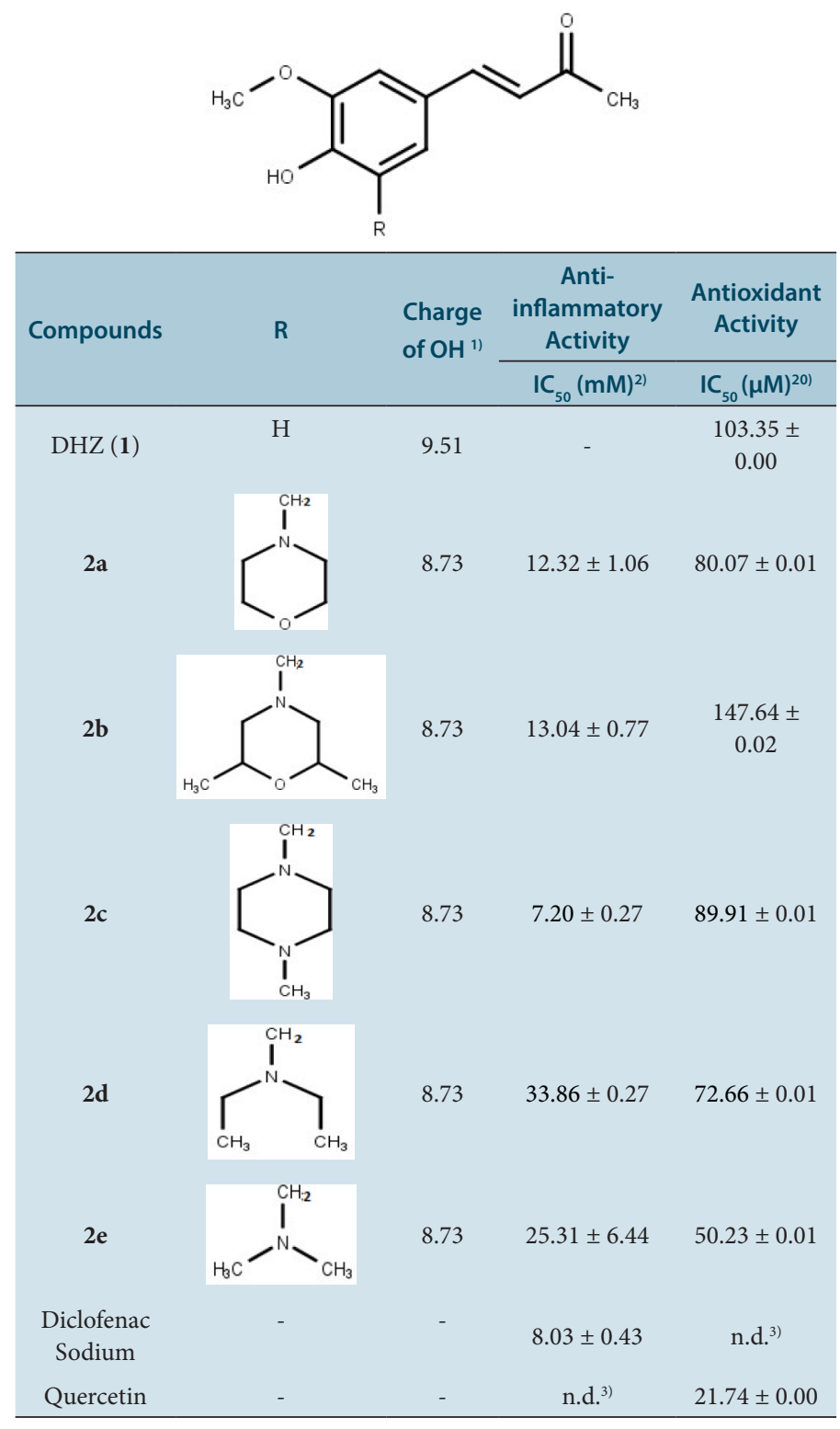

${ }^{1)}$ Calculated using MarvinSketch $6 \cdot 1 \cdot 0 \cdot{ }^{27} ;{ }^{2)} \mathrm{n}=3 ;{ }^{3)}$ n.d. = not detected

$\mathrm{C}-\mathrm{O}$ phenol, $\mathrm{C}$-O ether, and C-N; while the $\alpha, \beta$-carbonyl groups of the compound are observed as intense bands at $1660-1670 \mathrm{~cm}^{-1}$. In ${ }^{1} \mathrm{H}-\mathrm{NMR}$ spectra, the protons of the aromatic ring remained only two protons appeared at $\delta 6.8 \mathrm{ppm}(1 \mathrm{H})$, and $7.0 \mathrm{ppm}(1 \mathrm{H})$ as a doublet with $J=1-3 \mathrm{~Hz}$ indicated that the Mannich base substituted a proton at the ortho position relative to the $\mathrm{OH}$ phenolic group of compound $\mathbf{1}$. The data were supported by the disappearance of the broad peak of $\mathrm{OH}$ phenolic in the FTIR spectra of the compound because of the formation of intramolecular hydrogen bonding between the $\mathrm{OH}$ group and $\mathrm{N}$ atom of the Mannich base. ${ }^{21-22}$ The structures were further supported by ${ }^{13} \mathrm{C}-\mathrm{NMR}$ spectra which provided the expected number and types carbons of the carbonyl, aromatic, ethylenic and aliphatic moieties of the compounds, and by MS spectra which provided the molecular masses of the compounds. These values are in the complete agreement with the structure assigned.
The synthesized compounds (2a-e) were then screened for their antiinflammatory using inhibition of heat-induced albumin denaturation method and antioxidant activity using a free-radical DPPH scavenging activity model system.

The inhibitory of heat-induced albumin denaturation activity of the compound ranged in $\mathrm{IC}_{50}$ values from $7.20 \mathrm{mM}$ to $33.86 \mathrm{mM}$ (Table 1, Figure 2). In this series, the compound $2 \mathrm{c}$ containing $\mathrm{N}$-methylpiperazine moiety exhibited the highest activity, which was comparable with that of diclofenac sodium $\left(\mathrm{IC}_{50}=8.03 \mathrm{mM}\right.$ ), while the parent compound (DHZ, 1) did not exhibit the heat-induced albumin denaturation. The previous study reported that several anti-inflammatory drugs had shown the ability to inhibit heat-induced albumin denaturation. ${ }^{23-24}$ Another study indicated that although there was no complete correlation, several compounds of acetamido[(phenyl-4'-yl)-oxymethyl)]-2-(p-substituted phenylamino)-1,2,4-triazoles and -1,3,4-thiadiazoles which showed good inhibition of denaturation also exhibited significant in vivo antiinflammatory activity by carrageenan-induced edema in the rat paw. ${ }^{25}$ Therefore the title compounds promising to have potential anti-inflammatory activity.

The free-radical DPPH scavenging activity of the compounds ranged in $\mathrm{IC}_{50}$ values from $50.23 \mu \mathrm{M}$ to $147.64 \mu \mathrm{M}$ (Table 1, Figure 3). In this series, the compound $2 \mathrm{e}$ containing dimethylamine moiety was found to be the highest and showed moderate activity compared to that of quercetin $\left(\mathrm{IC}_{50}=21.74 \mu \mathrm{M}\right)$. Mostly the antioxidant activity of the Mannich bases derivatives of DHZ was higher than that of the parent compound (DHZ, 1) $\left(\mathrm{IC}_{50}=103.35 \mu \mathrm{M}\right)$. The previous study reported that the hydroxy phenolic group of DHZ is essential for antioxidant activity through hydroxy radical scavengers. ${ }^{3,26}$ The results indicate that most of the aminomethyl groups (Mannich bases) of the compounds enhance the ability of the hydroxy group to scavenge the radical. At curcumin analogs, the electrondonating groups are improving the antioxidant activity, ${ }^{27}$ while recent study reported that the Mannich base of cyclovalone derivatives containing dimethylamine and diethylamine moiety had a higher free-radical DPPH scavenging activity than that the parent compound. The higher the basicity of $\mathrm{N}$ atom of the Mannich base, the higher the activity. ${ }^{28}$ However, the relationship is not shown in the Mannich derivatives of DHZ. Therefore further studies need to be done to explain any factors affecting the antioxidant activity of phenolic compounds by the introduction of Mannich bases.

\section{CONCLUSION}

A series of five new Mannich bases of dehydrozingerone (DHZ) derivatives were synthesized successfully and evaluated for their anti-inflammatory activity through inhibiting heat-induced albumin denaturation and antioxidant activity employing free radical DPPH scavenging activity method. Using the method, all the synthesized compounds (2a-e) showed anti-inflammatory and antioxidant activity. Compound 2c containing $\mathrm{N}$-methylpiperazine moiety showed the highest antiinflammatory activity. The activity was comparable to diclofenac sodium. While compound $2 \mathrm{e}$ containing dimethylamine moiety exhibited the highest antioxidant activity. The compound exhibited moderate antioxidant activity compared to quercetin as standard.

\section{ACKNOWLEDGEMENT}

The authors are grateful to the Directorate of Research and Community Services, Universitas Indonesia, Depok, Indonesia, for the financial support of this research and to Laboratory of Organic Chemistry, Chemistry Study Program, Faculty of Mathematics and Natural Science, Bandung Institute of Technology (ITB), Bandung, Indonesia, for recording NMR and mass spectra data. 


\section{CONFLICT OF INTEREST}

The authors declare no conflict of interest.

\section{ABBREVIATIONS}

DHZ: Dehydrozingerone; TLC: Thin layer chromatography; FT-IR: Fourier transform infrared; NMR: Nuclear magnetic resonance; TMS: Tetramethylsilane; HRMS: High resolution mass spectrometry; ESITOF : Electrospray ionization-time of flight; UV-Vis: Ultraviolet-Visible; DPPH: 1,1'-diphenyl -2-picrylhydrazyl.

\section{SUMMARY}

A series of five new Mannich bases of DHZ derivatives was synthesized and evaluated for their antiinflammatory and antioxidant activity. The synthesis was performed by refluxing DHZ with formaldehyde and secondary amines, and the structures of the synthesized compounds were confirmed by FT-IR, ${ }^{1} \mathrm{H}-\mathrm{NMR},{ }^{13} \mathrm{C}-\mathrm{NMR}$, and HR-MS. The anti-inflammatory and antioxidant activity evaluations were done by inhibition of heat-induced albumin denaturation and a free-radical DPPH method, respectively. Results of the evaluations showed that all the synthesized compounds showed anti-inflammatory and antioxidant activity. The highest anti-inflammatory activity was shown by compound $2 \mathrm{c}$. The activity was comparable to that of diclofenac sodium as a standard. While, the highest antioxidant activity was demostrated by compound $2 \mathrm{e}$. The compound showed moderate activity compared to that of quercetin as a standard. Mostly of Mannich base derivatives of DHZ compounds exhibited higher antioxidant activity than that of DHZ.

\section{REFERENCES}

1. Profumo E, Buttari B, D'Arcangelo D, Tinaburri L, Dettori MA, Fabbri D, et al. The Nutraceutical Dehydrozingerone and Its Dimer Counteract Inflammation-and Oxidative Stress-Induced Dysfunction of In vitro Cultured Human Endothelia Cells: A Novel Perspective for the Prevention and Therapy of Atherosclerosis. Oxid Med Cell Longev. 2016:1-12.

2. Jayasekhar P, Santhakumari G. Pharmacological Activity of some Mannich Bases of Dehydrozingerone. Indian J Pharm Sci. 1998;60(4):191-5.

3. Kubra IR, Bettadaiah BK, Murthy PS, Rao LJ. Structure-function activity of dehydrozingerone and its derivatives as antioxidant and antimicrobial compounds. J Food Sci Technol. 2011;51(2):245-55

4. Hampannavar GA, Karpoormath R, Palkar MB, Shaikh MS. An appraisal on recent medicinal perspective of curcumin degradant: Dehydrozingerone (DZG) Bioorg Med Chem. 2016;24(4):501-20.

5. Dhanalakshmi T, Rajeshwari T, Raja B. Antioxidant activity of Dehydrozingerone on STZ and L-name induced oxidative stress in experimental rat model. World $\mathrm{J}$ Pharm Pharm Sci. 2014;3(9):1466-77.

6. Obregón-Mendoza MA, Estévez-Carmona MM, Hernández-Ortega S, SorianoGarcía M, Ramírez-Apan MT, Orea L, et al. Retro-Curcuminoids as Mimics of Dehydrozingerone and Curcumin: Synthesis, NMR, X-ray, and Cytotoxic Activity. Molecules. 2017;22:1-14.

7. Parihar VK, Dhawan J, Kumar S, Manjula SN, Subramanian G, Unnikrishnan MK, et al. Free radical scavenging and radioprotective activity of dehydrozingerone against whole body gamma irradiation in Swiss albino mice. Chem Biol Interact. 2007;170(1):49-58.

8. Yogosawa S, Yamada Y, Yasuda S, Sun Q, Takizawa K, Sakai T. Dehydrozingerone, a Structural Analogue of Curcumin, Induces Cell Cycle Arrest at the G2/M Phase and Accumulates Intracellular ROS in HT-29 Human Colon Cancer Cells. J Nat
Prod. 2012;75(12):2088-93.

9. Muškinja J, Ratkovic Z, Rankovic BB, Kosanic MM. Synthesis of O-Alkyl Derivatives of Dehydrozingerone Analogues. Kragujevac J Sci. 2016;38:97-106.

10. Burmud AZ, Muskinja JM, Kosanic MM, Rankovic BR, Novakovic SB, Dordevic SB, et al. Cytotoxic and Antimicrobial Activity of Dehydrozingerone based Cyclopropyl Derivatives. Chem Biodiversity. 2017;14:1-10.

11. Elias G, Rao MN. Synthesis and anti-inflammatory activity of substituted (E)-4phenyl-3-buten-2-ones. Eur J Med Chem. 1988;23(4):379-80.

12. Roman G. Mannich bases in medicinal chemistry and drug design. Eur J Med Chem. 2015;89:743-816.

13. Bandgar BP, Patil SA, Gacche, RN, Korbad BL, Hote BS, Kinkar SN, et al. Synthesis and biological evaluation of nitrogen-containing chalcones as possible antiinflammatory and antioxidant agents, Bioorg. Med Chem Lett. 2010;20(2):730-3.

14. Khan MS, Husain A, Sharma S. New 4,6-diacetyl resorcinol mannich bases: Synthesis and biological evaluation. Acta Pol. Pharm Drug Res. 2010;67(3):261-6.

15. Bala S, Sharma N, Kajal A, Kamboj S, Saini V. Mannich Bases: An Important Pharmacophore in Present Scenario. Intl J Med Chem. 2014;1-15.

16. Sinhababu AK, Borchardt RT. Selective Ring C-Methylation of Hydroxybenzaldehydes via Their Mannich Bases. Synth. Comm.: An Intl. J Rapid Comm Synth Org Chem. 1983;13(8):677-83

17. Yerdelen KO, Gul HI, Sakagami H, Umemura N. Synthesis and biological evaluation of 1,5-bis (4-hydroxy-3-methoxyphenyl) penta-1,4-dien-3-one and its aminomethyl derivatives. J Enzyme Inhib Med Chem. 2015;30(3):383-8.

18. Mahendran G, Manoj M, Prasad KJ, Bai VN. Antioxidants, anti-proliferative, antiinflammatory, anti-diabetic and anti-microbial effects of isolated compounds from Swertia corymbosa (Grieb.) Wight ex C.B. Clark - An in vitro approach. Food Sci Hum Wellness. 2015;4(4):169-79

19. Jayashree V, Bagyalakshmi S, Manjula DK, Richard DD. In vitro anti-inflammatory activity of 4-benzylpiperidine. Asian J Pharm Clin Res. 2016;9(2):108-110.

20. Dhanalakshmi T, Rajeshwari T, Raja B. Antioxidant activity of Dehydrozingerone on STZ and L-name induced oxidative stress in experimental rat model. World $\mathrm{J}$ Pharm Pharm Sci. 2014;3(9):1466-77.

21. Silverstein RM, Webster FX, Kiemle DJ. Spectrometric Identification of Organic Compounds, $7^{\text {th }}$ ed., 2005, John Wiley and Sons, Inc. New York, NY, USA. 2014

22. Dank C, Felsinger S, Kirchknopf B, Mastalir M, Kählig H, Roller A, et al. Hybrids of Salicylalkylamides and Mannich Bases: Control of the Amide Conformation by Hydrogen Bonding in Solution and in the Solid State. Molecules. 2015;20:1686-711

23. Grant NH, Album HE, Kryzanauskas C. Stabilization of serum albumin by antiinflammatory drugs. Biochem Pharmacol. 1970;19(3):715-22.

24. Saso L, Valentini G, Casini ML, Grippa E, Gatto MT, Leone MG, et al. Inhibition of heat-induced denaturation of albumin by nonsteroidal antiinflammatory drugs (NSAIDs): pharmacological implications. Arch Pharm Res. 2001;24(2):150-8.

25. Nargund LV, Redd GR, Hariprasad V. Inhibition of albumin denaturation and anti-inflammatory activity of acetamido-[(phenyl-4'-yl)-oxymethyl)]2-(p-substituted phenylamino)-1,2,4-triazoles and -1,3,4-thiadiazoles. Indian J Exp Biol. 1993; 31(4):395-6.

26. Nugroho AE, Yuniarti N, Estyastono EP, Supardjan, Hakim L. Determination of antioxidant activity of dehydrozingerone through hydroxy radical scavengers using deoxyribose method. Ind J Pharm. 2006;17(3):116-22.

27. Zheng QT, Yang ZH, Yu LY, Ren YY, Huang QX, Liu Q, et al. Synthesis and antioxidant activity of curcumin analogs. J Asian Nat Pro Res. 2017;19(5):489-503.

28. Hayun H, Jatmika C, Purwati EM, Salim S, Kurniawan R, Chandra EG, et al. Synthesis and Free Radical-scavenging Activities of Di-Mannich Bases of Cyclovalone Derivatives. Orient J Chem. 2017:33(6):2742-57. 